\title{
The Role of Charismatic World Trade Organization and the expansion of Free International Trade
}

\author{
Muhammad Saqib Irshad ${ }^{1}$, Qi Xin², Muhammad Ayaz ${ }^{3}$, Faizan $\mathrm{Ali}^{4}$ \\ ${ }^{1234}$ School of Economics, Department of International Economy and Trade, Tianjin University of Finance \\ and Economics, No.25 Zhujiang Road, Hexi Dist., 300222, Tianjin, China. \\ Correspondent Author's e-mail: mohd_saqib_malik@hotmail.com, sarahqixin008@hotmail.com
}

\begin{abstract}
One of the most significant occurrences over the last two decades in the area of economic desegregation was the sharp increase in bilateral, multilateral and regional trading arrangements since the end of the Uruguay Round in 1994. It is extensively believed that the international trade organization, WTO, increases trading systems and encourages trade. Pursuing free trade by WTO has numerous attractions. It is clear that free trade enhanced among WTO member countries but seems most favorable for rich countries and little bit glitch for developing nations. Countries bind themselves and their trading collaborators to transparent and non-discriminatory trade regulations and rules, which the WTO then implements even handedly. As a consequence, much consideration is paid to the exceptional needs and tribulations of developing and transition economies.
\end{abstract}

Keywords: WOT, RTA, FTA, GATT, Free Trade

\section{Introduction}

Today's World in the epoch of globalization seeing as the beginning of the third millennium, because economies started out to be integrated since then in terms of goods, traditions, trade, investments and various others factors. According to the International Monetary Fund (IMF), surrounded by the most fundamental aspects of globalization comprises the trade and transactions, movements of capital and investments as well as migration or movement of people and last but not least dissemination of knowledge (IMF, 2000). In other expressions, globalization is the march of the interconnection of peoples or nations in different ways and across bigger distances (Lechner, 2009). Furthermore, Held (2000) ${ }^{\mathrm{i}}$ acknowledged that globalization is the advance internationalization of economic activities or actions.

Since 1947 throughout 1994, the most significant mechanism for encouraging and regulating International trade was General Agreement on Tariffs and Trade (GATT). GATT was launching after the failure of state legislature to reach agreement on the minutiae for an International Trade Organization (ITO). GATT wraps International trade in goods. The functioning of GATT agreement is the liability of the committee for trade in goods (goods council) which is made up of representatives from the entire World Trade Organization affiliate countries. According to Yu (1999), the main objective of establishing the GATT was in order to perpetrate countries in preserving the principle of nondiscrimination and reciprocity, when it approaches to trade. Conversely, Robb (2001) assumed that its key function was to lesser the trade barriers, rather than to compose them harmonized. Following points in depth is designed to understand some the fundamental economic principles behind international trade. 


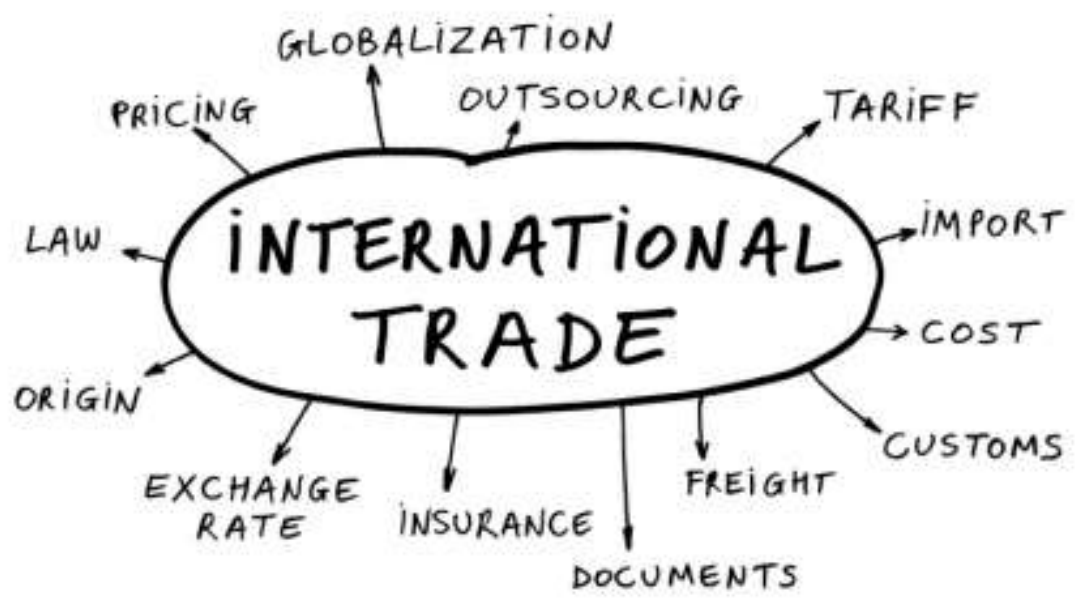

Figure 1: Fundamentals of International Trade

It is extensively believed that the international trade organization, WTO, increases trading systems and encourages trade (Myeong, 2010). The World Trade Organization or WTO was shaped in the year 1995. The core objective of WTO is to facilitate the trading industry to grow to be smooth, fair, liberated and knowable. It was structured to become the decision maker of multilateral trade and trade agreements among its member countries. It endures all occurring talks for newest agreements for trade. WTO furthermore attempts to resolve trade conflicts among member nations. A member country involuntarily becomes part of the "Most Favored Nations." Holding the status of being one of the "Most Favored Nation" gives approach to discounted tariffs and slighter trade barriers, excessive regulation system and import quotas that are all the privileges for WTO's members. These favors pave way to better market for the members' goods which consequences to extra sales, more jobs and healthier economic growth. Over 75 percent of the members are ranked as developing economies. Through their membership by WTO, they can smoothly penetrate the market of developed economies at lesser tariffs. Simultaneously, developing economies are also decreasing tariffs in their import market. By doing this practice, developing economies are using the opportunity to develop and expand their corporations and industries into extra mature and superior kind until they become competitive to the region of developed economies.

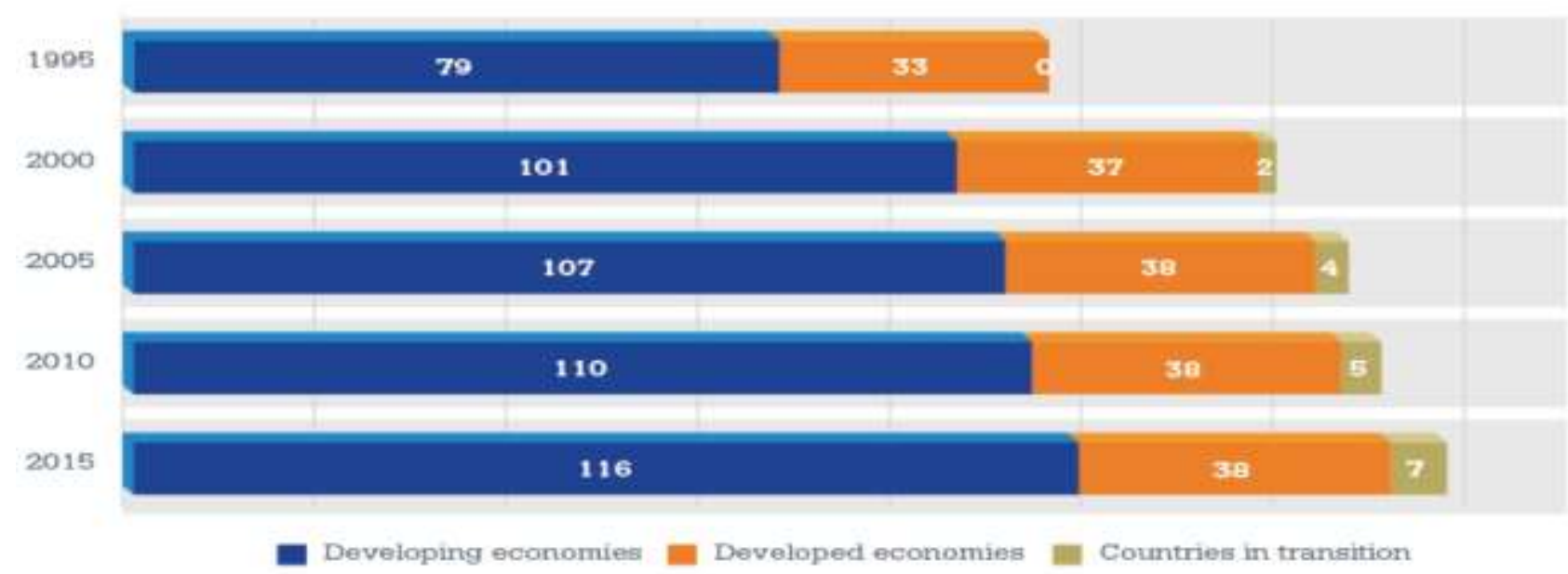

Figure 2: Expansion of WTO membership (1995-2015)

Source: WTO, International Trade Statistics 2015

WTO membership has grown to 161 nations as of August 2015, with 33 economies having joined the WTO since 1995. From 1995 to 2014, WTO members' share of merchandise exports raised from 89 percent of total exports in 1995 to 94 
percent in 2005 and to 97 percent in 2014. WTO places amongst the most important role in promoting free international trade. Pursuing free trade by WTO has numerous attractions. Countries bind themselves and their trading collaborators to transparent and non-discriminatory trade regulations and rules, which the WTO then implements even handedly. ever since most governments run on the foundation that opening domestic markets is a concession to be traded for entrance to foreign markets, multilateral liberalization is frequently the most effective and successful route to free trade.

\section{Principles of WTO}

Established in 1995 after the 8 years "Uruguay Round" of talks, it came through the General Agreement on Tariffs and Trade (GATT), which was shaped in 1948 to lesser trade barriers. The scope of the WTO is bigger, however, including services, intellectual property and agriculture, not just trade in goods.

Table 1: The core principles of the WTO (Source: The WTO and Free Trade by (Shah, 2007))

\begin{tabular}{|c|c|}
\hline Principles & Explanation \\
\hline Non discrimination & $\begin{array}{c}\text { National treatment implies both foreign and national companies are treated the same, and } \\
\text { it is unfair to favor domestic companies over foreign ones. Some countries have a most } \\
\text { favored nation treatment, but under WTO the policy is that all nations should be treated } \\
\text { equally in terms of trade. Any trade concessions etc. offered to a nation must be offered to } \\
\text { others. }\end{array}$ \\
\hline Reciprocity & Nations try to provide similar concessions for each other. \\
\hline $\begin{array}{c}\text { Special and } \\
\text { differential treatment }\end{array}$ & Recognition that developing countries may require "positive discrimination" because of \\
historic unequal trade.
\end{tabular}

According to WTO, the agreements are long-drawn-out and complex because they are legal texts wrapping a wide range of actions and activities. They deal with: agriculture, textiles, clothing, banking, telecommunications, government purchases, industrial standards and product safety, food sanitation regulations, intellectual property, and much more. However, a number of simple, elementary principles run during all of these credentials. These principles are the base of the multilateral trading system.

A closer look at these principles:

\section{- Trade without discrimination}

a) Most Favored Nation(MFN):Treating other people equally

Every member treats all the other members equally as "most-favored" trading allies. If a partner improves the gains that it gives to one trading nation, it has to grant the same "best" dealing to all the other WTO members so that they all stay "most-favored". MFN position did not always indicate equal treatment. The first bilateral MFN treaties set up exclusive groups among a country's "most-favored" trading nations. Under GATT and now the WTO, the MFN group is no longer exclusive. The MFN belief ensures that each nation treats it's over 140 members equally.

b) National treatment: treating foreigners and locals equally

Imported and locally-manufactured goods should be treated uniformly at least after the overseas goods have entered the market region. The similar should apply to international and domestic services, and to overseas and local trademarks, copyrights and patents. National treatment only utilizes once a product, service or item of intellectual property has entered the market. Consequently, accusing customs duty on an import is not an infraction of national treatment even if domestically-produced products are not filed an equivalent tax.

\section{- Freer trade: gradually, through negotiation}

Lessening trade barriers is one of the most apparent ways of encouraging trade. The barriers anxious include customs duties (or tariffs) and actions such as import bans or quotas that confine quantities selectively. Commencing time to time other issues for instance red tape and exchange rate policies have also been discoursed. Opening markets can be favorable, but it also involves adjustment. Developing economies are generally given longer to accomplish their obligations. 


\section{- Predictability: through binding and transparency}

Occasionally, promising not to lift a trade barrier can be as significant as lowering one, because the guarantee gives businesses a clearer vision of their future opportunities. Through stability and unavoidability, investment is encouraged, jobs are formed and consumers can completely enjoy the benefits of competition - choice and lesser prices. The multilateral trading system is an effort by governments to formulate the business environment stable and predictable.

\section{- Promoting fair competition}

The WTO is sometimes reported as a "free trade" body, but that is not exclusively accurate. The system does permit tariffs and, in partial circumstances, other kinds of protection. More precisely, it is a system of rules and regulations dedicated to open, fair and accurate competition. Several of the other WTO agreements intend to support fair competition: in agriculture, intellectual property, services, such as. The agreement on government procurement broadens competition system to purchases by thousands of government entities in several economies.

\section{- Encouraging development and economic reform}

The WTO system imparts to development. Alternatively, developing countries require flexibility in the moment they take to execute the system's agreements. And the agreements themselves acquire the former provisions of GATT that permit for special assistance and trade concessions for developing economies.

More than three quarters of WTO members are developing nations and nations in transition to market economies. During the seven and a half years of the Uruguay Round, more than 60 of these nations implemented trade liberalization programmers separately. At the same time, developing economies and transition economies were much more vigorous and influential in the Uruguay Round talks than in any previous round, and they are even more so in the recent Doha Development Agenda.

\section{Expansion of International Trade and Agreements}

The remarkable growth of international trade over the past several decades has been mutually a primary cause and outcome of globalization. The size of world trade augmented twenty-seven fold from $\$ 296$ billion in 1950 to $\$ 8$ trillion in 2005(WTO, 2007). Although international trade experienced a contraction of 12.2 percent in 2009-the steepest decline since World War II-trade is again on the upswing (WTO, 2010). Growth in the volume of world merchandise trade will spontaneous only slightly over the next two years, growing from 2.8\% in 2014 to $3.3 \%$ in 2015 and eventually to $4.0 \%$ in 2016 (WTO, 2015). World merchandise trade is expect to grow $3.3 \%$ in 2015 in capacity terms as output picks up slightly in equally developed and developing countries. Trade expansion should accelerate to $4.0 \%$ in 2016, still under the average of 5.1\% since 1990, and well below the pre-crisis average of $6.0 \%$.International trade is explained as a contract where two parties or countries (These parties or companies may operate their business in dissimilar countries trading in goods and services) enters into the contract of buying and selling of goods and services despite of national boundaries. This includes the import and export trade where one nation either sells goods or service to other nation or buys goods and service from other nation (Law, 2016). Over the past 20 years, trade has been influenced by many factors, including advances in information technology, financial crises, growing membership of the WTO, natural disasters and geo-political tensions. These have led to volatility in commodity prices, changes to the leasing traders and their trading partners, and the growing importance of services trade. Since last two decades trade has been an important factor in helping to boost economic growth and to lift millions of people out of poverty. According to WTO (2015) the top 10 traders in merchandise trade accounted for 51 percent of the world's total trade in year 2014 and developing countries had a 41 percent share of world merchandise trade in the same year. Merchandise exports from WTO members totaled US\$ 18 trillion in year 2014. Trade in goods and services have fluctuated considerably over the last two decades.

- Since late 1990s, trade flows rose steadily. This was followed by a muscular rise in the early years of 2000s and a sharp drop after the economic crisis in 2008. Recent years have observed a moderate improvement.

- Trade went through fairly strong growth from 1995 to 2001, chased by a boom from 2002 to 2008 accompanied by growing commodity price. Subsequent the financial crisis in 2008, trade fell suddenly in 2009 before rebounding strappingly in 2010 and 2011. Despite the fact that, trade growth since then has been uncommonly weak. 
- China's attainment to the WTO in December 2001 cemented the way for its economic rise and extensively contributed to growing world trade from 2002 to 2008.

- Giant Chinese demand for natural resources contributed to increasing prices for crude oil and supplementary primary commodities between 2002 and 2008.

- Exports of goods recovered in 2010, with a growth rate of 14 percent in volume terms. But, the recovery was vulnerable by a boost in oil prices in 2010, partially as a consequence of political instability in oil-producing countries.

- Debt crises and governments tensions deepen in 2014, causing world trade to slow to a creep over the last few years. In value terms, world merchandise trade development averaged just 1 per cent per year from 2012 to 2014.

- International trade in commercial services has been less impulsive than merchandise trade in the last two decades, demonstrating the greater resilience of services to world macroeconomic turbulence.

- Over the last two decades, global services trade has recorded negative only once (9 per cent in 2009), in the wake of the worldwide financial crisis. In 2010, services trade recommenced its pre-crisis stage and has continued to swell steadily even though sluggish economic growth.

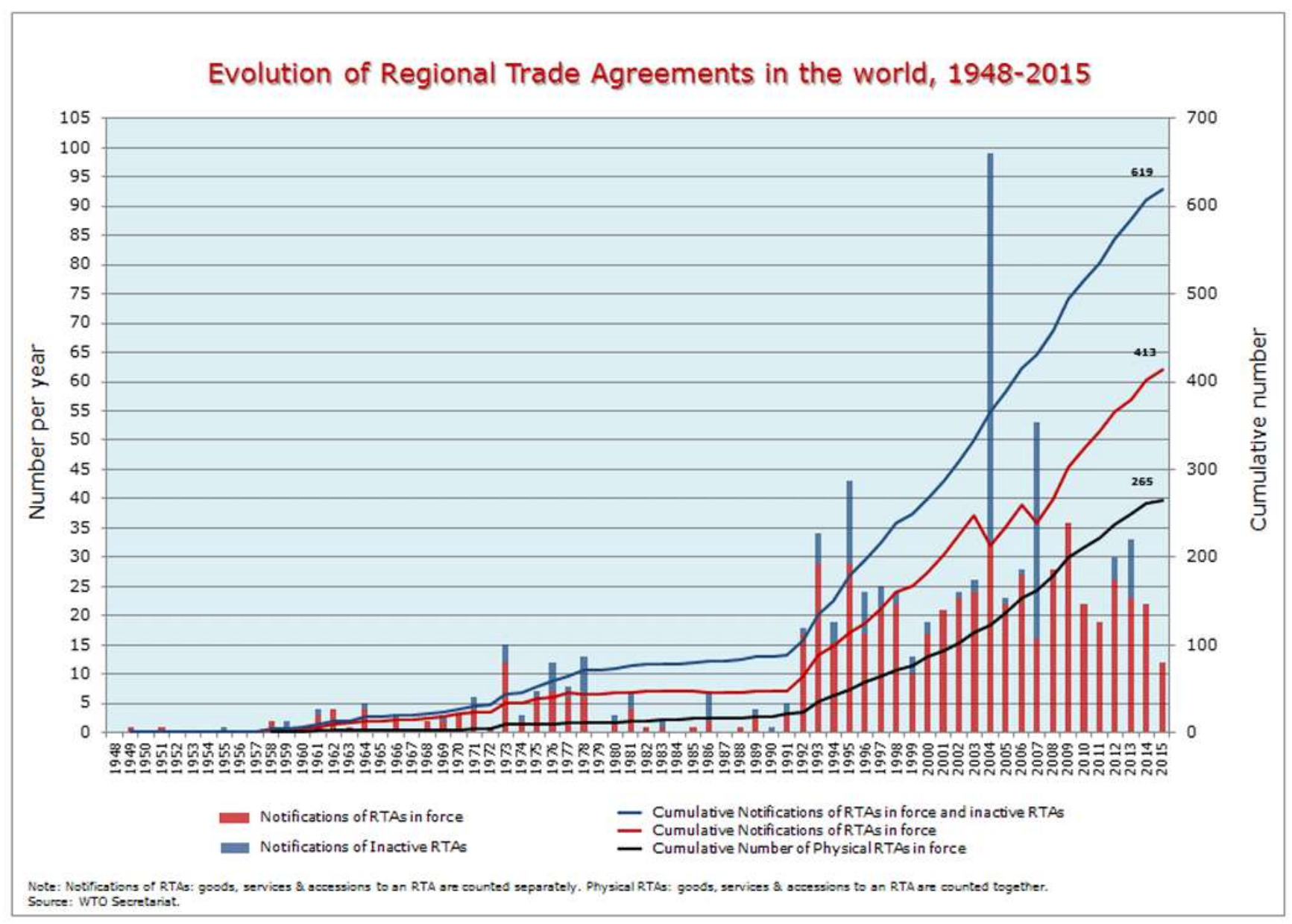

Figure 3: Evolution of Regional trade agreements in the World under GATT/WTO (1948-2015)

Multi-lateral agreements are always made between several nations in the past. Because of this, such agreements become very complicated to consult but are so powerful and influential once all the parties agree and sign the multilateral agreement. WTO acts as the administrator. An important feature of the WTO's mandate is to collaborate with the International Monetary Fund, the World Bank and other multilateral institutions to accomplish greater coherence in worldwide economic policy-making. The announcement envisages an amplified contribution by the WTO to reaching greater coherence in worldwide economic policy-making. It recognizes the connections between special aspects of economic policy and calls on the WTO to widen its cooperation with the international organizations liable for monetary 
and financial matters - the World Bank and the IMF. The declaration also distinguishes the contribution that trade liberalization constructs to the expansion and development of national economies. It visions such liberalization as a progressively more important component in the achievement of the economic modification programs, which various WTO members are undertaking, although it may often involve important transitional social costs. The network of preferential trade agreements (PTAs) wraps most nations in a complex way. The inclination towards "regionalism," a movement to form regional trade agreements, has been gradually growing particularly since 1980s (Bhagwati, 1993) Since the Treaty of Rome recognized the European Economic Community (EEC) in 1957, the European Union (EU) has been developing with the accession of new members.

\section{The bumpy road towards liberalization (Some Disputes)}

Reality is harsh and not much convincing for the developing countries. Disputes in WTO are regarding broken promises. Predominantly and on document the above broad objectives sounds excellent but when it comes down to reality, the reality becomes the nightmare for the developing economies. The declared aim of the WTO is to encourage international trade and to endorse economic growth and developments among all of his members. Nevertheless, the measures and methods of the WTO suggested strong aversions. Along with other things, the WTO is accused of expanding the social gap between rich and poor it claims to be conciliating (Solanki, 2012).

WTO has received harsh appreciation from various third world countries. Several of such criticisms are:

- One of the illustrations is the system of tariff brokering (commission) that takes position through WTO itself who aims to lessen barriers to trade. The WTO policies allow a nation to defend certain industries if the elimination of tariffs would have unwanted side effects, which comprise the failure of essential home industries. Foodstuff production is one of the most general, but auto production, steel construction and several others can be added at the discretion of the country (Andrew, 2008).

- One more critic is about tribulations of implementation of the Uruguay Round. The fact is the Northern economies have not lived up to the courage of their commitments in employing their obligations granted to in the various Agreements (Wikipedia)

- Critics of the WTO confront that the WTO has not sustained the essential factor of transparency. It is never comprehensible which nations are in on the supervisory processes. In such situations the politicians can negotiate for policies and regulations that would not be tolerated in a democratic process in their own economies. This is frequently referred to as Policy Laundering (Solanki, 2014).

- Beginning and introduction of TRIPs into the WTO structure is also disputed below the fear that such nontrade schemas might sweep over the organization's function.

\section{Conclusion}

With the abovementioned explanation, it can be concluded that WTO has huge impacts to the international flow of trade, investments and trade agreements. The WTO is an international organization, which not only encourages of the international trades but also energetically participates on business creativeness. It always put required effort to keep the peaceful trans-boundary trades and to solve the disagreements if arises among the member. Although there are various views on role of WTO but as far as my view is concerned, WTO plays a significant and affirmative role for promoting the international trades and surely beneficial for the countries to trade trans-boundary being the part of the WTO.

WTO has a significant impact on the flow of commodities and investments. Reuvid and Sherlock (2011) acknowledged that WTO, for example, was competent to be successful in conquering protectionism. This is due to the different policies, strategies and instruments that this organization was able to manage and institutionalize among its associates. According to (Schaffer et al, 2008) stated that among numerous agreements and policies of WTO that have an impact to world trade contain the investment actions and intellectual property rights. Particularly, the organization has the biggest influence in upsetting tariffs, import duties and further trade barriers (Wyndham-White, 1961). Moreover, in a research of Kaberia (2007), the impact and responsibility of WTO was assessed to some of its members and that proves WTO genuinely promotes International trade. Apart from that, these trade-promoting organizations also facilitate to make things easier, extra convenient and valuable, in terms of trading and investment. Consequently, these proceedings contribute for improved integration of the world in order to solve common problems and disputes. 


\section{References}

- Andrew, B. (2008). The dark side of the WTO, Accessed from (http://www.investopedia.com/articles/economics/dark-side-of-the-wto.asp\#axzz26B8ku5Ze), Retrieved at 22 January 2016.

- Anup Shah, (2007). The WTO and Free Trade, Global issues. Retrieved from (http://www.globalissues.org/article/42/the-wto-and-free-trade), Accessed on 15 Jan 2016.

- Bhagwati, J., 1993. Regionalism and multilateralism: an overview. In: de Melo, J., Panagariya, A. (Eds.), New Dimensions in Regional Integration, World Bank and Cambridge University Press, Cambridge, pp. 22 51, CrossRef

- Criticism of the World Trade Organization, Retrieved from (http://en.wikipedia.org/wiki/Criticism_of_the_World_Trade_Organization), Accessed on 01 February 2016.

- Held, D., (2000). A Globalizing World?: Culture, Economics, Politics. 1st ed. Sweden: The Open University.

- International Monetary Fund - IMF (2000). Globalization: Threat or Opportunity. Retrieved from (http://www.imf.org/external/np/exr/ib/2000/041200to.htm), Accessed 10 Jan 2016.

- Kaberia, D. K. (2007). World Trade Organization (WTO) and its Role in International Trade: with Case three Case Studies (Philippines, China and United States of America).

- LawTeacher, UK. (November 2013). What Role Does The Wto Play In International Business International Law Essay. Retrieved from (http://www.lawteacher.net/free-law-essays/international-law/what-role-does-thewto-play-in-international-business-international-law-essay.php?cref=1 ), Accessed on 20 January 2016.

- Lechner, F. J., (2009). Globalization: the Making of World Society. 1st ed. Singapore: Utopia Press Pte. Ltd.

- Myeong Hwan Kim (2010). Does the WTO Promote Trade? Further Evidence. Journal of International Trade \& Economic Development.19 (3), 421-437, CrossRef

- Reuvid, J. and Sherlock, J., (2011). International Trade: An Essential Guide to the Principles to the Principles and Practice of Export. 1st ed. India: Kogan Page Publishers, Inc.

- Robb, Cairo A. R., (2001). International Environmental Law Reports; Trade and Environment. 2nd ed. United Kingdom: Cambridge University Press.

- Schaffer, R., Agusti, F., and Earle, B., (2008). International Business Law and its Environment. 7th ed. Canada: Cengage Learning.

- Solanki, (2012). Globalization and role of WTO in promoting free international trade, IOSR journal of humanities and social Science, Volume 3, Issue 1, pp 11-14, October 2012.

- Solanki, (2014). Globalization and role of WTO in promoting free international trade, AE international journal of multi-disciplinary research, volume 2, issue 1, January 2014.

- Understanding the WTO, Retrieved from (http://www.wto.org/english/thewto_e/whatis_e/tif_e/disp1_e.htm), Accessed on 15 January 2016.

- World Trade Organization. (2007). The GATT/WTO at 60: WTO world trade report examines six decades of multilateralism in trade. Retrieved from https://www.wto.org/english/news_e/pres07_e/pr502_e.htm

- World Trade Organization. (2010). Trade to expand by 9.5\% in 2010 after a dismal 2009, WTO reports [Press release].Retrieved from https://www.wto.org/english/news_e/pres10_e/pr598_e.htm

- World Trade Organization. (2015). Modest trade recovery to continue in 2015 and 2016 following three years of weak expansion. Retrieved from https://www.wto.org/english/news_e/pres15_e/pr739_e.htm

- Wyndham-White, E., (1961). GATT as an international trade organization: some structural problems of international trade. 1st ed. Switzerland: World Trade Organization.

- Yu, L., (1999). The International Hospitality Business: Management and Operations. 1st ed. New York: Haworth Hospitality Press, Inc. 